University of Warwick institutional repository: http://go.warwick.ac.uk/wrap This paper is made available online in accordance with publisher policies. Please scroll down to view the document itself. Please refer to the repository record for this item and our policy information available from the repository home page for further information.

To see the final version of this paper please visit the publisher's website. Access to the published version may require a subscription.

Author(s):Christopher Browning and Pertti Joenniemi Article Title: Geostrategies of the European Neighbourhood Policy Year of publication: 2008 Link to published version: http://dx.doi.org/10.1177/1354066108092311

Publisher statement: None 


\section{Geostrategies of the European Neighbourhood Policy}

\section{Christopher S. Browning}

School of Politics, International Relations and Philosophy, Keele University,

Keele,

Staffordshire,

ST5 5BG,

UK.

c.browning@intr.keele.ac.uk

\section{Pertti Joenniemi}

Danish Institute for International Studies,

Strandgade 56,

DK-1401 Copenhagen K,

Denmark.

pjo@diis.dk

tel: +453269 8958

Acknowledgements: We would like to thank Pami Aalto, Stuart Croft, Marko Lehti, Viatcheslav Morozov and the anonymous reviewers for their comments. 


\section{Geostrategies of the European Neighbourhood Policy}

\section{Introduction}

Since the end of the Cold War debates about Europeanness, of who are and who are not members of this privileged category, have been intimately tied to membership of the European Union. In the early part of the 1990s idealism about creating a 'Europe whole and free' was widespread and was closely associated with EU enlargement. As we know, turning rhetoric into reality has been a slow process and following the 2004 enlargement questions about the EU’s (and hence Europe’s) final borders - which have never been far from the surface - have become matters of considerable debate at both political and popular levels. This has been particularly evident in the debate over Turkey's possible future membership, which has left people raising questions as to what the characteristics of Europeanness are and whether they are culturally, racially, religiously or geographically grounded.

Beyond concerns over preserving particular essentialised notions of 'European’ identity, there have also been concerns over the need to preserve the significant gains of the European project. Enlargement fatigue has been accompanied by worries that the recent expansion to 27 members may turn the EU into a bureaucratic dinosaur and further undermine the democratic legitimacy of the Union. In this respect, the desire to draw the final borders of (EU) Europe has become a matter of existential importance for many in 
the Union, the belief being that continued expansion will not only make the Union unworkable, but may actually threaten its durability. Thus, whilst people may disagree on where the final borders of (EU) Europe should be drawn, the belief that Europe's finalite should soon be decided is widely held.

Questions of the Union's borders, however, cannot be separated from questions regarding the Union's security. This is particularly so since the EU has explicitly used the promise of future membership in order to promote stability along its borders. Drawing 'final' borders therefore poses the EU with a dilemma of how it will promote stability and security in its neighbouring regions if the carrot of enlargement is no longer available. The EU's current answer to these issues, of where to draw the final borders of the Union and how to promote security and stability beyond that border, have been presented in its developing European Neighbourhood Policy (ENP). The optimism that this policy framework can achieve these goals is evident in the policy's proclaimed ambition that the neighbouring countries will constitute a benevolent and stable 'ring of friends'.

In the academic literature on the ENP such optimism has been contentious. As Scott (2005: 430) notes, analyses have been polarised between those that view the ENP as driven by neo-liberal/neo-imperialist assertions of economic hegemony, and those that champion it as 'a potentially progressive form of "post-Westphalian” and "postmodern” regionalism'. In this respect, the tendency has been to view the ENP as a reflection of a

\footnotetext{
${ }^{1}$ The concept is used among other places in the Commission's March 2003 communication on the Wider Europe: "The EU should aim to develop a zone of prosperity and a friendly neighbourhood - a 'ring of friends' - with whom the EU enjoys close, peaceful and co-operative relations.....” (European Commission, 2003: 4).
} 
rather fixed geopolitical vision of what the EU is about and how it aims to run and organise the broader European space. One of the contentions of this article is that adopting such fixed frameworks fails to capture some of the key dynamics that are emerging as the ENP develops, whilst it also condemns the EU as lacking capacities of social learning.

This article therefore aims to retain space for viewing the ENP as a developmental and somewhat fluid process by showing where pressures for change and reorientation may lie, thereby avoiding the temptations of a deterministic condemnation or celebration of the policy. Theoretically this is achieved in two parts. In the next section the article discusses three geopolitical models that are frequently invoked when trying to conceptualise the evolving nature of the EU. These models are those of a Westphalian, Imperial and Neomedieval Europe. However, whilst there is a temptation to reify the differences between these models, and not least also the trajectory of the EU's geopolitical development, in the following section, we utilise a framework recently employed by William Walters (2004) to conceptualise a series of different geopolitical strategies (geostrategies) employed by the EU in regard to its borders and near abroad. Geostrategies can be seen as sets of competing and overlapping discourses concerned with how to organise territory and space at the border, and how to relate to the otherness beyond. Our argument is that whilst particular geopolitical models/visions may lend themselves to particular geostragies (and vice versa), there is also considerable fluidity present, with the EU at times emphasising one geostrategy over others, or emphasising different ones in different geographical contexts. 
This enables us to tell a more dynamic story regarding the developing nature of the ENP, of some of the criticisms it has faced, and not least regarding what the ENP experience may say about the EU's evolving nature. In short form, the following analysis illustrates how and why the ENP emerged as a somewhat reactive and defensive policy driven by a desire for homogenisation and standardisation of EU policy towards its new neighbourhood. In turn this has become a standard point of critique of the ENP, the view being that the generalisation of the ENP from its original focus on the eastern border, to the EU's borders as a whole, has created a one-size-fits-all policy inappropriate to dealing with the specificities of the EU's various borders. In turn this has prompted criticisms that, despite its stated aims, the ENP will not solve the EU's security concerns regarding its external borders because it will fail to extricate the EU from a logic that links external security with the need for further integration of outsiders.

Whilst we agree that an overarching imperial geopolitical vision has been present in Commission documents on the ENP we argue this has been complicated by the fact that this imperial geopolitical model has been coupled with different geostrategies in different regional contexts. Ultimately the existence of these different geostrategies of the march, limes, colonial frontier and networked (non)border complicate what is actually meant when analysts label the EU as having a tendency towards 'imperial-type' policies. In part, what this complex intermingling of geopolitical models and geostrategies indicates is the extent to which the ENP is being shaped by discourses and practices coming from both the EU centre as well as from the regions. Having laid out the conceptual frame the final 
part of the paper demonstrates how differentiation has begun to make its way onto the ENP agenda by pointing to the fluidity with which the EU employs geostrategies along its external border. The result, we argue, is that the geopolitical visions and geostrategies adopted at different points along the border ultimately means that the 'geopolitical nature' of the EU looks different depending on whether one is looking from a southern, eastern or northern perspective. Conceptualising the ENP in such discursive terms leaves space for seeing the dynamism present within the ENP, as well as for highlighting the critical role that outsiders and those on the margins can play in not only shaping EU border policies, but also geopolitical visions of Europe more broadly.

\section{Models of European Geopolitics}

As noted, since its inception debates have raged both about the ultimate character of the European Union (EU) and its final borders. It has become common to posit ideal models to try and capture the EU's evolution, the three most common being those of a Westphalian, Imperial and Neomedieval Europe (see figure 1) (Browning, 2005).

\section{INSERT FIGURE 1 HERE}

The Westphalian model depicts the EU steadily coalescing and assuming all the characteristics of modern statehood as sovereignty is steadily moved away from the states to the Commission in Brussels. Power, in this model (and as indicated by the arrows in 
the figure), is seen as held at the centre but as applied consistently over the territory up until the border, where one sovereign territoriality meets another. ${ }^{2}$ Evidence for such a modernist model is often drawn from the oft-stated desire that the EU should develop into a unitary actor, that it should have its own currency and border regime (Schengen), and not least its own foreign and security policy including a foreign service and a 'European army'. Most recently the allure of statist terminologies within the European project has been evident in the desire to provide it with a constitutional treaty, though as Christiansen (2005: 73) notes, despite the ensuing brouhaha over its ratification, in legal terms it was always a constitutional treaty rather than a European constitution. As such, although its detractors find the Westphalian metaphor attractive to mobilise popular opinion, the intergovernmental nature of the Union undermines the utility of this model.

Unlike the Westphalian metaphor that depicts the EU as having clearly defined statist borders across which governance is relatively uniform, the Imperial model depicts EU governance in terms of a series of concentric circles. Power, here, is understood as located at the centre in Brussels and dispersed outwards in varying, multilayered and declining degrees (Wæver, 1997; Zielonka, 2001: 509). A geopolitical drive premised on an imperial logic has been evident in the EU in at least two respects. First, notions of the EU as possessing a 'peace mission' to bring stability throughout Europe have provided the EU with both moral and identity prerogatives to try and organise the space beyond its borders and to spread 'European values' to those on the outside. Slogans of building a 'Europe whole and free’ and a 'Europe without dividing lines' reflect such an endeavour.

\footnotetext{
${ }^{2}$ On modernist/Westphalian approaches to territoriality see Ruggie (1993).
} 
Second, this desire to foster stability and security through the spread of 'European values' and practices is also enhanced by 'security discourses'. As Tassinari (2005: 1) notes, the EU has traditionally been stuck in a dilemma between balancing desires for further integration with those of ensuring the Union's security (also see Smith, 2005). The point is that the EU has tended to see its outside as a source of instability and insecurity. This has resulted in two policy responses. First, there has been a desire to preserve the security of the inside by asserting the need for the Union to develop rather impermeable borders to keep the danger excluded at the gates of a fortress Europe, as evident, for example, in Westphalian readings of the Schengen visa regime (Grabbe, 2000). Second, however, to overcome the external threat and to live up to EU ideals of an open peace project, policies have also been developed to extend EU systems of governance to those beyond its borders in order to bring stability and security. This has been achieved through a variety of measures from the Association Agreements to the Balkans Stability Pact, to the EuroMediterranean Partnership, to the NDI. Central to the effectiveness of most of these policies has been the conditionality mechanism by which states that comply with EU reform goals are rewarded with a closer relationship with the EU. The ultimate carrot has been EU membership, at which point, however, the integration-security nexus begins all over again in relation to the EU's new neighbours.

However, whereas previously the EU has deferred the question of its final borders by pushing forward with another round of enlargement, it appears this is no longer possible. The constitutional crisis and the widespread scepticism regarding future enlargement to countries like Turkey, Ukraine, Belarus, Moldova, let alone states in North Africa, seems 
to have taken enlargement off the agenda for the time being and has meant the EU needs a new policy both to cope with and hopefully overcome this integration-security dilemma' - that is, how to promote stability and security without having to rely on the carrot of future enlargement. The ENP is designed to fill this gap.

The third geopolitical model is that of a neomedieval Europe. The neomedieval metaphor depicts power in Europe as dispersed in a more radical fashion to that of the Imperial or Westphalian models, with power no longer fixed on a single centre in Brussels, but as being far more regionalised and corresponding to logics of transnationalism and network governance, depending on the particular issues at play. In this respect, Scott (2005: 444) speaks of a geopolitics of 'dimensionality' 'where geopolitical thought is informed by many "centres" rather than by one dominant "core"'. This model also resonates with the multilevel governance literature (e.g., Filtenborg et al., 2002; Ruggie, 1993) where European governance is seen as focused more around issue networks than territorial spaces. Conceptualised slightly differently it has also been visualised in terms of a 'Europe of Olympic Rings' in which regionality becomes the core constitutive organising principle of European political space and where governance, authority and decisionmaking is dispersed and brought closer to the people (Joenniemi, 2000: 129-31; Medvedev, 2000: 100).

It is in northern Europe where ideas of a regionalised and neomedieval Europe have been most clearly embraced. This has been particularly notable in Finland's promotion from 1997 (Lipponen, 1997) of the Northern Dimension Initiative (NDI) as a part of the 
external policies of the EU and which has been seen to challenge centralist understandings by locating subjectivity and power in the margins and regions. One interesting aspect of the NDI, for example, is its use of the term 'North', rather than 'Nordic'. This was a deliberate attempt to leave the borders of the North (and therefore also the EU) open and inclusive. Notably, commentators have pointed out that the benefit of the North lies precisely in its symbolic value as a largely blank space where new stories of togetherness might be written and new relationships forged in the process of overcoming entrenched stereotypes embedded in the concepts of East and West (Medvedev, 2001). The North transcends East-West divides and entails thinking about borders in rather open terms.

Importantly, the NDI has promoted a rather neomedieval geopolitical vision of European political space, especially to the extent that it has entailed an emphasis on developing a regional space that transcends the EU's borders and where regional partners and EU outsiders (especially Russia) have been understood as equal partners in the formulation and implementation of projects. The NDI's vision, therefore, has been of contributing to a rather decentralised Europe, where regions might become constitutive entities in their own right and where space has been provided for outsiders to have a genuine voice in European border policies (Christiansen, 1999: 194). In practice, of course, the NDI has not always operated in accordance with the rhetoric. At times neomedieval decentralisation and openness has been replaced by an emphasis on asserting the hegemony of the centre in a more imperial fashion. Partly this has been because the EU sometimes finds it difficult to step outside hierarchical depictions of itself in relation to 
its outside. Rhetorically this has been evident in how Russians have often remained objects of EU discourse 'to be saved', with Russia seen as having little to offer its Western neighbours (aside from natural resources) (Browning, 2003). ${ }^{3}$ However, to pay too much attention to the limitations of the NDI is to miss the point that the very exercise has been highly innovative, putting onto the EU agenda an alternative model of European geopolitics and governance.

\section{Conceptualising EU Border Geostrategies}

Highlighting these different geopolitical models (widely employed by others) is the first part of our conceptual framework to try and capture the developing nature of the EU and European space and governance. Arguably, however, this framework lacks sufficient explanatory power on its own because it is overly parsimonious and lacks dynamism. The problem is that discussion of geopolitical models easily results in their reification and a simplification of the nature of the policies under analysis, not least because one can be westphalian, imperial or neomedieval in different ways, whilst one may be more than one of these at the same time in different locations. We therefore propose supplementing the framework of geopolitical models with a scheme developed by William Walters for thinking about the various geostrategies the EU employs along its borders.

\footnotetext{
${ }^{3}$ This has also been evident in visual representations of the NDI as presented in a video posted on the website of the Finnish Ministry of Foreign Affairs in 1999, A Northern Dimension for the Policies of the European Union virtual.finland.fi/finfo/english/northdim2.html. At the same time, the decentralised neomedieval visions of the NDI have also been undermined by Russia, which at times has viewed its emphasis on the exploitation of the resources of north-west Russia as thinly veiled neo-imperialism. Similarly, Moscow has also worried that the decentralising and regionalising aspects of the initiative would grant Russia’s north-west regions too much freedom and encourage the final break up of Russia (Haukkala, 2001; Joenniemi and Sergounin, 2003.
} 
For Walters the term geostrategies refers to particular border discourses as opposed to broader geopolitical visions.

[A] geostrategy corresponds with a particular way of organising the space of the border. It presupposes many things, including particular definitions of the 'inside' and 'outside' of the polity, the types of threat or problem which the border is to address, and specific accounts of the time and the space of the border. Geostrategies entail certain territorialisations. Each implies a particular form of controlling space and population. But they also presuppose particular definitions as to the identity and political rationality of Europe (Walters, 2004: 675).

Different geostrategies, therefore, entail particular mental geographies and perceptions of particular landscapes and territories. They entail particular ways of approaching and dealing with the land, of how to move within it and how to change and order it. Thus, they are not simply descriptions of what is, but are also prescriptive of how one relates to the land and tries to shape it. ${ }^{4}$ Walters contends that multiple geostrategies are evident in EU border policies. Furthermore, these can coexist in the discourses surrounding individual policies, with particular geostrategies being more important in some contexts and times than at others. As such, Walters asserts that geostrategies should not be seen as totalising descriptions of reality, but as frames built on particular logics.

\footnotetext{
${ }^{4}$ There is an interesting similarity here with the concept of 'mindscape' developed in Liulevicius (2000: 151).
} 
Geostrategy is to be understood at the level of political aspirations, objectives and ambitions. To identify particular geostrategies is not to assume that these aspirations are necessarily accomplished or fully realised. Hence, to speak of ... [a particular geostrategy]... is not to imply that the EU's frontiers fully conform to these images, only that this is one possible play of forces or line of development. The geostrategy is more a case of a certain will to shape reality according to a particular image than an actual state of affairs. This theoretical position means that we can acknowledge the possibility of multiple geostrategies converging on, and investing a particular, borderspace (Walters, 2004: 679).

\section{INSERT FIGURE 2 HERE}

More particularly, Walters identities four EU geostrategies (see figure 2). The first is the networked (non)border. This geostrategy resonates with ideas of deterritorialisation and a borderless world that are clearly evident in postmodernist debates about Europe, as well as in globalisation studies. This geostrategy, he notes, is underlain by neoliberal concerns to remove obstacles to the free movement of people, goods and services and of overcoming the barriers which divide Europe - all goals clearly stated in the core EU treaties (Walters, 2004: 679). Also central to this geostrategy is the view that spatial borders - lines on the ground - are becoming less relevant. For example, policing and systems of control that used to take place at clearly defined border lines is increasingly being dispersed throughout the territory, as well as taking place in close (networked) cooperation with outsiders. In this respect, the whole national/European territory has become conceptualised as a borderspace, whilst 'effective frontier control is to be sought through cooperation between state agencies on both sides of the frontier' (Walters, 2004: 
$680,682)$. Instead of us-them divides, this geostrategy envisages sharing responsibility with outsiders and emphasising strategies that transcend traditional views of borders.

The second geostrategy is that of the march. Marchs can be understood as indistinct zones separating different entities; a kind of running out and intermingling of space between groups. Walters refers to the Anglo-Welsh marchs of earlier times when English and Welsh settlements along the frontier were often interspersed and the border between inside and outside fluid. In other ways the march might be perceived as a border area, 'an interzone between powers', or even as a buffer zone (Walters, 2004: 683-84). The German concept of Zwischeneuropa (Europe Between) to describe the border zone of East European states separating Russia (the East) from Western Europe is another manifestation of this idea (Saarikoski, 1997). Understood as a buffer zone, however, the implication is that the march is a geostrategy that perceives a particular space as a security zone separating the cosmos from the chaos outside, it is a protective belt keeping the disorder (beyond Eastern Europe) at a distance. However, Walters indicates that the march might be a dynamic phenomenon in itself. Thus, if prior to 2004 the EU perceived central and eastern Europe as a buffer zone of security, with enlargement they are now on the inside and a new buffer zone further to the East is being envisaged.

The third geostrategy is that of the colonial frontier. This geostrategy conceives of the frontier as 'a dynamic space, a meeting point between a power, a culture and its outside. It is a space of interaction, assimilation, violence but also pacification' (Walters, 2004: 687). Importantly the colonial frontier is mobile and conceived as something to be 
expanded and projected outwards. More particularly, the notion of the colonial frontier is also infused with a power asymmetry in which 'the expanding power assumes a right to define what is appropriate and just. It is an organisation of political space in which the centre is the acknowledged repository and arbitrator of what is proper' (Walters, 2004: 688). Central to this geostrategy, therefore, is the notion of the transformation of the outside in line with the preferences of the inside and the outside's gradual incorporation within the inside.

The fourth geostrategy is that of the limes. As Walters (2004: 690) puts it: 'If the space of the march is an area between powers, an interzone, and that of the modern frontier a finite line demarcating and separating territories, then the limes is more like an edge, fringe or limit'. In some respects the limes is similar to the spatial imagination of the colonial frontier, with one significant difference. Whilst the geostrategy of the colonial frontier perceives the frontier as open to expansion, a geostrategy of the limes perceives the frontier as more permanent, even if somewhat hazy. Like the colonial frontier the limes draws a hierarchy between the inside and outside and institutionalises asymmetric relations between unequal powers; however, whereas the colonial frontier aims to incorporate the outside into the inside, the limes is more about drawing a limit of expansion and consolidating and preserving what the empire has achieved and incorporated (Walters, 2004: 691).

Having laid out Walters' four geostrategies it is tempting to associate them directly with the particular geopolitical models (Westphalian, Imperial, Neomedieval) noted above. 
For example, the geostrategy of the colonial frontier clearly resonates with the model of Imperial Europe, and might be seen as manifested in the idea of the Union as having a Europeanising vocation and civilising mission to project itself beyond its borders. Similarly, the geostrategies of the march and of the networked (non)border might respectively be tied to the Westphalian and Neomedieval models, with the march emphasising the externalisation of threats and a defensive strategy of exclusion, whilst the networked (non)border rather emphasises policies of decentralisation, networking and treating the outside as equal partners.

It is, however, important to remain open about this. As noted an imperial model might also be tied to a geostrategy of the limes, whilst linking the models and geostrategies too closely arguably precludes two things. First, it makes it harder to conceptualise the fact that the different models and geostrategies will be present in different strengths at the same time and in different locations. Second, it also makes it harder to see that the geostrategies and models might actually meld into each other over time. For example, a geostrategy of the limes (which entails a somewhat defensive reading of security and of the possibilities of transforming the outside), might over time meld into a colonial frontier geostrategy (which aims to transform the threatening outside into oneself and as such entails a positive attitude as to the possibilities of achieving this) (Walters, 2004: 692). The point, therefore, is that it depends on whether the empire is in an expansionist or consolidative mode at that particular border. 
Having laid out this combined framework, in the following we show how different geostrategies and geopolitical visions have been prominent at different points in time and in regard to different parts of the EU's new neighbourhood in respect of the EU's new European Neighbourhood Policy (ENP). Thus, whilst it makes sense to speak of certain geopolitical visions and geostrategies dominating or transforming into others in some contexts, others will be most relevant at other locations along the border.

\section{European Neighbourhood Policy}

As indicated above, with the last round of enlargement the EU has been compelled to coin an increasingly explicit geopolitical doctrine to deal with the challenges posed by its new neighbours. This is because the previous stance of promised future membership in return for reforms is now off the agenda for the foreseeable future. Despite possible exceptions (e.g. Turkey, Western Balkans) increasingly it is being argued the EU has reached its territorial limits. In this section, therefore, we further highlight some of the initial rationale behind the ENP and point to how it has been interpreted in the ensuing academic debate around the policy. Focusing primarily on EU (rather than regional) level discourses we demonstrate how it has become easy to label the ENP as an exercise founded on an imperialist geopolitical model of the EU vis-à-vis its neighbourhood. However, what we also demonstrate is that the nature of this 'imperialist' model has not been straightforward, but has been complicated by the existence of different geostrategies. In the article's final section we then complicate the picture even further by 
focusing on how the ENP has been mediated through more regional specific discourses, with these having important constitutive effects on what the ENP and 'EUrope' may look like in different regional contexts.

In their simplest form the challenges understood as posed for the EU by the 2004 enlargement in respect of the new neighbours were threefold. First, how to avoid the alienation of its new neighbours? Second, how to promote reform when the EU's primary carrot of future membership is no longer available? Third, how to avoid the EU external border becoming a line of exclusion and negative othering?

In the academic literature it is commonly argued that the ENP, in its current framing, is unlikely to provide the answer to any of these challenges. This is because ultimately, and despite aspirations otherwise, the ENP fails to transcend the 'integration-security dilemma' that has driven its approach to its border states in the past. This has led commentators to argue that the ENP has so far remained premised on an imperial geopolitical vision, conceiving of its outside in terms of what Emerson (2002) calls a hierarchical 'friendly Monroe doctrine'. However, if the geopolitical vision/model behind the ENP has been an imperial one, this imperialism, we argue, has actually been imbued with different geostrategies to different degrees. Indeed, geostrategies of the limes, march and colonial frontier have all been apparent, which complicate what it means to talk of the ENP as promoting an imperial vision of the EU in Europe. Thus, whilst the policy's initial over-riding logic and rationale has arguably been one of a limes geostrategy (of consolidating the empire and drawing final borders in view of the recent enlargement), 
geostrategies of the colonial frontier and the march have also played important roles in the discourse.

Evidence to suggest that the ENP has so far been unable to transcend the integrationsecurity dilemma, and as such reproduces an imperial logic for the EU, is often seen in that the new neighbourhood created by the 2004 enlargement has primarily been viewed as a source of threats to the EU (Jeandesboz, 2005). The documents that initiated the process of formulating a more explicit policy stressed needs such as avoiding 'the risk of negative spillover' - with such 'threats' usually conceived in terms of illegal immigration, terrorism, organised crime, communicable diseases, and social problems associated with poverty, etc. ${ }^{5}$ However, the threat is also conceived in terms of enlargement itself, where the ENP has been presented precisely as a policy to stave off future enlargements that would undermine the EU's overall coherence, legitimacy and viability. Either way, the outside has been conceived as something to be kept outside and guarded against. ${ }^{6}$

Notably, however, instead of simply drawing a line of ultimate exclusion, as would be dictated by a modernist Westphalian view of the EU, external threats are to be countered by EU attempts to order the space beyond its borders through the export of EU norms and

\footnotetext{
${ }^{5}$ The UK letter that sparked off the process in 2002 underlined that 'Within three years, Ukraine and Belarus will border the EU - with all the attendant problems of cross-border crime, trafficking and illegal immigration. Moldova will not be an EU neighbour until later [....] but it already faces grinding poverty, huge social problems and mass emigration'. Letter from Jack Straw to Josep Piqué (Foreign Minister of Spain), Foreign and Commonwealth Office, London 28 January 2002. Whereas the UK letter was mainly premised on perceptions of threat, the letter sent somewhat later by the Swedish Minister of Foreign Affairs (Rengeringskansliet, Stockholm, 8 March 2002) emphasized the duty of the EU to formulate policies in view of the 'Big Bang'. For an analysis, see Jeandesboz (2005).

${ }^{6}$ As Pardo (2004: 735) puts it, the aim has become one of keeping the chaos on the outside, whilst at the same time trying to enhance security by keeping the outside friendly.
} 
practices. Thus, in the view of Del Sarto and Schumacher, the driving motivation for the establishment of the 'ring of friends' has been the security concern to create a buffer zone between the EU's inside and outside. Ironically, this is to be achieved by to some extent blurring the external border with its immediate neighbours in some areas, in order to make those neighbours responsible for effective control of their borders with neighbours even further to the East and South - thereby pushing the threat of the outside away from the EU's own borders (Del Sarto and Schumacher, 2005: 19, 25-6). Blurring is thus understood as a way to push threats further away and is illustrative of a more general imperial framework in how the EU looks at its outside. More specifically, however, the emphasis on creating a security buffer zone resonates with geostrategies of the limes (of consolidating the empire) and march (of pushing the threat beyond). To reaffirm, therefore, this 'buffering logic' does not result in a modernist, Westphalian approach to the EU's borders (of drawing a strict line separating inside and outside), but rather sees the EU’s governance as 'fading out' into the space beyond in a more concentric, imperial pattern. In this respect, the concept of the 'ring or friends' promotes a hierarchy of otherness in that the drawing together of a group of 'friends' is also a way by which those 'friends' are also designated as 'foreign' (at least more foreign than 'candidate' countries), whilst those outside the 'ring of friends' are condemned to another implicit category of 'non-friends' or 'geographical others'.

However, despite the emphasis on the dangerous and threatening others to be kept outside geostrategies of the colonial frontier are also evident in EU discourse surrounding the ENP, where a more positive view of the possibilities of transforming the outside (and 
potentially even incorporating it) remain evident. This is evident, for example, in that despite the stress on discourses of 'threat', at times emphasis has also been placed on the Union's self-conceptualisation as a peace project with a mission to spread its values to the rest of the world, which is seen to provide the EU with a duty to face up to the challenges posed by the nearby areas in more constructive ways beyond adopting solely exclusionary or security driven policies (Ferrero-Waldner, 2005). Thus, the European Commission (2004: 3) has declared that the aim of the ENP is also to 'share the benefits of the EU's 2004 enlargement with neighbouring countries in strengthening stability, security and well-being'. Likewise, at times commonalities of interests between the EU and its new neighbours have been stressed and seen as an opportunity for the Union (Ferrero-Waldner, 2005). These discourses of duty and opportunity arguably resonate more with a colonial frontier geostrategy since they have entailed a more explicit belief in the possibilities of transforming the outside in line with EU preferences and are indicative of an EU that retains expansionist ambitions in this regard.

Even more notable, however, is that a colonial frontier geostrategy appears embedded in the very traditional mechanism of conditionality the EU is using to implement the ENP and which it might be argued provides a further reason why the ENP is unlikely to transcend the integration-security dilemma. Conditionality is evident in that the ENP rests on promises to upgrade political and economic relations with the partner countries (to the extent that the EU's Four Freedoms might be extended to them in their entirety ${ }^{7}$ ) in

\footnotetext{
${ }^{7}$ The Four Freedoms relates to the freedom of movement of goods, capital, people and services. This goal reflects Romano Prodi's oft stated comment that what is on offer in the ENP is 'everything but institutions'. As one of the Commission documents puts it, 'all the neighbouring countries should be offered the prospect
} 
return for tangible progress in implementing internal reforms. The previous logic behind enlargement therefore remains intact, except now it is emphasised that everything is possible bar institutions (i.e. membership). ${ }^{8}$ As noted by Berg and Ehin (2006: 60), 'Central to the neighbourhood paradigm is the notion of conditionality - a system of sticks and carrots in which soft and open borders constitute a reward for progress in meeting European standards'. The alternative, though, is also possible with the EU emphasising it may also punish countries through a partial or total suspension of assistance if neighbours' commitments are not met (European Commission, 2004: 3). In other words, the EU is setting conditions that have to be met in order to qualify for inclusion in the category 'friends'.

Importantly, however, the reliance on the conditionality mechanism has enabled the Commission to stress the ENP as being open to 'differentiation', as being founded in ideas of 'partnership' and as a process of 'joint ownership' 'based on the awareness of shared values and common interests' (European Commission, 2004: 3) between the EU and its partners. Although the established institutional borders are to remain untouched without the option of any further enlargement, the approach outlined by the Commission is presented as rather inclusive with the stress on making borders fluid and mobile. In short, the conditionality mechanism means that some states will integrate further than others. The conditionality mechanism, therefore, is designed to enable the Union to

of a stake in the EU's Internal Market and further integration and liberalisation to promote the free movement of persons, goods, services and capital (four freedoms)' (European Commission, 2003: 10).

${ }^{8}$ In Smith's (2005) view this position is unrealistic, since why would outsiders bother to go through the trauma of transition if they are to be denied equal status. As such she argues the emphasis on conditionality ultimately means the ENP will fail to transcend what we have termed here the integration-security dilemma. 
extend parts of the acquis communautaire to the non-member states. This process is becoming formalised with the partner countries expected to sign Action Plans as a basis upon which their performance can then be evaluated through country reports covering progress on implementation. ${ }^{9}$

However, despite notions of 'differentiation', 'interdependence' and ‘joint ownership’ ENP commentators have criticised that the emphasis is rather on standardisation and homogeneity and for asserting the EU's hierarchical position in rather traditional imperial fashion. Standardisation is evident in the ENP's overall aim of consolidating the Union's policies towards its near abroad. Instead of having a variety of policies such as the NDI and the Euro-Mediterranean Partnership and so forth, the initial aim has been to supersede these with the single ENP, a move Gromadzki et al. (2005: 14) contend creates the 'misleading perception that a similar (although differentiated) relationship model suits all the countries" and glosses over the fact that such a "broad strategy does not respond to the specific aims of the neighbours' (Also see Albioni, 2005: 2). ${ }^{10}$

Meanwhile, hierarchical elements in the ENP stem directly from the emphasis on conditionality and which means notions of ‘joint ownership’ ultimately are widely seen to add up to little. Thus, it is the EU that is setting the goals of the specific ENP Action Plans and that will decide if they have been implemented or not (Gromadzki et al., 2005:

\footnotetext{
${ }^{9}$ For a description and analysis on the ENP, see for example Emerson and Noutcheva (2005). As Smith (2005: 764-5) notes, the actual criteria for assessment is far from clear. For example often it is unclear who is responsible for undertaking an action or exactly how progress will be judged.

${ }^{10}$ Similarly, the previous proliferation of financial instruments (TACIS, Interreg, MEDA etc.) will be ended with their amalgamation into a single financial instrument - the European Neighbourhood and Partnership Instrument (ENPI) - which is to be operational from 2007.
} 
16). Consequently, the idea that the parties to each Action Plan will have an equal voice has seemed naïve to many. As Del Sarto and Schumacher note, the various 'benchmarks' being established that will become a precondition for an enhanced partnership with the EU are being imposed by the EU. 'The Commission does not leave any doubts that the "commitment to shared values" - such as democracy, liberty, rule of law, respect for human rights and human dignity - refers to the values of the EU and its Member States' (Del Sarto and Schumacher, 2005: 23-4; Scott, 2005: 440). This is also clear in that the goals of the different Action Plans are almost identical (Knio, 2005). Another point that further emphasises the current hierarchical nature of the ENP and the EU's dominance over the partners is that no new institutions are being established to coordinate it. That is to say the Commission has argued that there is no need for a separate (and neutral) Secretariat to be established to coordinate the implementation, operation and evaluation of the ENP agreements. Instead the Commission has asserted that it will take on these coordinating roles, thereby further undermining the level of 'ownership' and 'equal partnership' possible in the ENP (see Pardo and Zemer, 2005). And as noted above, conditionality also entails the EU retains the right to 'punish' partners for insufficient progress through partial or total suspension of assistance.

Finally, it should also be stressed that the ENP has so far been premised on bilateralism rather than multilateral or regional approaches. As such the new neighbours have been targeted individually instead of being encouraged to coalesce as a group in negotiating with the EU. The justification for such an approach is that it enables the Union and its partners to tailor cooperation to the specific needs of individual countries. However, from 
a more Realpolitik perspective critics note that bilateralism accentuates the power asymmetries that exist between the Union and its weaker neighbours and makes the stress on 'bilateralism' appear little more than a cover for EU unilateralism (Vahl, 2005: 57; Tassinari, 2005: 5). As such, bilateralism appears premised on hierarchical structures that may undermine the possibilities for de-centralising governance by stressing local and regional endeavours. It may be noted, however, that due to considerable criticism the Commission appears to be on its way of softening its initial approach by intending, among other things, to organise a high-level conference with all ENP-partners invited 'in order to enhance the mutual ownership of the ENP' (European Commission, 2006: 14).

In short, when looking at broad debate on the ENP it has become common to argue that the ENP enhances the imperial characteristics of the EU, with governance and authority becoming centred on the core and power and subjectivity being dispersed out to declining degrees in a series of concentric circles. However, if the ENP appears to be supporting an imperial geopolitical model for the EU, the above analysis has also highlighted how this imperialism has been under-girded by different geostrategies. Thus, whilst the overall rationale of the policy has been defensive and concerned with consolidating and preserving the Union's gains (limes geostrategy), this has easily morphed into geostrategies of the march (creating a buffer zone to the threat beyond) and colonial frontier (an expansionist attempt to transform and incorporate the other). As such, if the ENP is promoting an imperial vision of Europe, then the picture of just what type of empire we are talking about and just how this empire relates to its borderlands and outside appears more complicated. For example, whilst the limes and march geostrategies 
read the outside in largely threatening terms, as something to be kept at bay, a colonial frontier geostrategy is more overtly expansionist, aiming at the transformation of the outside. This obviously raises further questions concerning the balance between the geostrategies in ENP discourses and policies. To what extent, for example, is one geostrategy being prioritised over the others, or is it possible to identify a shift in emphasis across time? To properly understand the picture and to begin to answer these questions it is necessary to look at how the ENP has begun to play out in different regional contexts.

\section{A Region Specific View of the ENP}

Adopting a more regionalised take on the unfolding of the ENP is important because for the most part this has been ignored as a result of the general trend towards standardisation and homogeneity in the policy. Indeed, analyses assessing the impact of the ENP on particular regional contexts have tended to highlight precisely the lack of flexibility in the policy and the problems that developing a one-size-fits-all approach will have for the region in question. In this respect, Smith has been keen to point out that with its emphasis on bilateral agreements between the EU and individual partner countries little space has been provided for more regional perspectives. As she puts it, 'the EU has evidently concluded that the way to foster peace and prosperity in the neighbourhoods is to foster reform in each neighbour first' (Smith, 2005: 771). In her reading this is why the EU has not inserted a strong regional, much less multilateral, component in the ENP. 
However, despite the absence of any clear regionalist mechanisms in the ENP we argue that the ENP is unfolding in quite different ways at different points along the EU's border. On the one hand, this is reflective of different emphasis being placed on the geopolitical models and geostrategies of what the EU is understood to be about in different contexts, which in part reflects the different interests and perspectives of member states and the various EU institutions. On the other hand, it also relates to the constitutive role of the neighbours in also framing the bounds of conceptual possibility at different points along the border. This provides for a rather more complex picture of European geopolitics in the ENP than is usually recognised.

\section{Eastern Neighbourhood}

It is interesting to start with the EU's eastern neighbourhood, since it was with regard to this region that the ENP was originally formulated in the first place and which can also explain why the ENP has become infused with an emphasis on bilateralism over multilateral/regionalised approaches.

Given that the 2004 enlargement overwhelmingly entailed the accession of countries from central and eastern Europe, it was not surprising that the EU felt a need to develop a new policy (then termed the Wider Europe initiative) to frame the relationship with its new eastern neighbours, Belarus, Moldova and Ukraine, and also initially Russia as well (European Commission, 2003). The inclusion of Russia, however, became perceived as 
problematic for all sides. Russia, for example, complained that its inclusion would equate it with countries such as Belarus and Moldova and worried that the homogenising bilateralism of the ENP, which promotes equality between the partners, contradicted Russia's aspirations of devising a privileged partnership with Brussels. ${ }^{11}$ Ultimately Russia opted out of the ENP in favour of developing a separate bilateral 'strategic partnership' that has become based on the development of the four 'common spaces' and that has therefore helped maintain the appearance of Russia as primus inter pares in the EU's relations with its neighbours (Gromadzki et al., 2005: 44; European Commission, 2004: 4). From Russia's perspective the strategic partnership signals Russia's distinctiveness and greater importance in comparison to the ENP countries, whilst it is also taken to imply a more genuinely equal relationship with the EU since the 'road maps' promoting the common spaces are to be based on principles of reciprocity, rather than EU-dictated conditionality (Zaslavskaya, 2005).

However, there were also doubts within the EU and the other partners about the inclusion of Russia, especially if a multilateral approach was adopted in the ENP. The issue for the EU was that pursuing a multilateral strategy would have compelled it to define the position of Russia in regard to the other partner countries in the ENP, with the fear being that ultimately Russia might try to dominate the eventual relationship, or at least inhibit the options available for the other countries of the region to get closer to the EU. In other words, in promoting a multilateral approach the EU may have ended up legitimising Russian dominance of the regional setting on the eastern borders (Smith, 2005: 772).

\footnotetext{
${ }^{11}$ For an extensive analyses of Russian attitudes towards the ENP see, Averre (2005).
} 
From its beginning, therefore, the ENP was infused with defensive elements as regards how to mediate between the EU's relationship with Belarus, Moldova and Ukraine and its relationship with Russia. Soft security issues, however, were also high up the agenda and have remained so and have been no more evident than in trying to make the eastern partners implement EU border policies on their eastern borders. And last but not least there was also the concern to create a policy that would ward off the perceived 'danger' of the expectation of any future enlargement of the EU to the East and to draw a clear distinction between Belarus, Moldova and Ukraine and the nearby candidate countries of Romania and Bulgaria.

In its initial phases, then, the Wider Europe initiative resonated particularly with a defensively oriented limes geostrategy as regards the new eastern neighbours. The goal was to consolidate the gains of enlargement, to provide the EU with time and space to absorb its new members, whilst also trying to develop a policy that would enable the EU to try and influence internal developments in the new neighbours by offering closer economic relations in return for reform. Elements of a march geostrategy, however, were also clearly evident, in particular in trying to create a buffer zone to the regions of greater instability further to the east in the Caucasus, the assumed source of many soft security threats to the EU. At the same time, elements of maintaining a buffer zone with Russia were also apparent.

However, this frame of dealing with the eastern neighbours primarily through the lenses of security and of trying to keep the outside outside and at bay has been problematic from 
the beginning, not least because of the aspirations of the eastern neighbours to become future EU members. The gradual democratic and economic transformation of these countries, most notably symbolised in Ukraine's Orange Revolution, and their claims to be a part of European history and the European heritage of nations has meant that the question of further enlargement simply will not go away. Appealing to EU norms and values and a common European history has played strongly on EU identity narratives that make permanent exclusion of the eastern neighbours deeply problematic. A key point here is that when the leaders of the Orange Revolution professed Ukraine’s desire to 'join Europe' this claim to Europeanness was not challenged in the EU, but rhetorically supported. Thus, whilst the eastern neighbours remain conceived as others of the EU, they are not depicted as threatening radicalised others, but rather as 'inferior' and somewhat 'backward' others, but ultimately with the potential to become like us (Tiirmaa-Klaar, 2006). In this context a colonial frontier geostrategy that paves the way to more explicit engagement beyond the EU's external border, that believes in the transformative potential of the neighbours, and that ultimately entails an idea of further expansion has come to make much more sense in the eastern neighbourhood. Moreover, the outsiders' refusal to let the membership issue lie and their willingness to comply with EU conditionality mechanisms (so long as membership seems a realistic prospect) has also been important in drawing the EU increasingly towards a much more engaged colonial frontier geostrategy that perceives the EU as an Empire still in expansionary mode. And finally, it should also be noted that these aspirations have also received broad support from the EU's new eastern members who have actively promoted the need of the EU to remain open towards the new eastern neighbours (as for example evidenced in 
Poland's proposals for an Eastern Dimension to complement the NDI (Cimoszewicz, 2003; Ministry of Foreign Affairs, 2001; Browning and Joenniemi, 2003)), and in some instances have been keen to assert that enlargement should not be taken off the agenda as regards these states - and thereby pushing a different view to that of the EU as a whole. Indeed, the Commission, for its part, has in a more recent document opened up the prospects for the ENP partner countries 'to participate in certain Community agencies and programmes', albeit it is added that 'the ENP remains distinct from the process of EU enlargement' (European Commission, 2006: 2, 9, 13).

\section{Southern Neighbourhood}

In contrast, along the southern border in the Mediterranean region things have looked rather different. Instead of a softening of the border the opposite might rather be happening, with a limes geostrategy being reinforced and to some extent even contributing to a rather Westphalian conception of a fortress Europe, where the outside is to be kept out behind an impermeable defensive border and where the outside is also perceived as largely unreformable.

Three key elements appear to be central in this respect. First, despite the fact that the ENP talks of enhancing democracy, integration, welfare and security in all the partner countries it is important to remember that the ENP was a policy initially formulated to respond to perceived problems arising in the East following the enlargement. The expansion of the policy to cover EU neighbourhood relations in general was the result of 
pressure from southern EU member states concerned that the EU's focus would unduly shift to the East. In this respect the key conceptual activism behind the ENP has remained focused on the East, with the result that its subsequent application also to the southern neighbourhood has entailed certain problems. As Pace (forthcoming) notes, one of the major problems with the ENP is that unlike the previous Euro-Mediterranean Partnership (EMP - Barcelona Process), which was based on the principle of 'regionality', the ENP rather emphasises 'differentiated bilateralism'. This change in emphasis not only undermines the development of regional cooperation (and therefore might adversely affect the EU's contribution to things like the Middle East Peace Process), but also reasserts a much more hegemonic and imperial role for the EU in the region.

Second, especially since the advent of the war on terrorism there has been a growing tendency on the part of the EU to prioritise questions of security, especially issues of migration, trafficking and terrorism in the region as a threat to the EU. The conflation of these threats has been notable, whilst the fact that the perpetrators of the Madrid rail bombings in 2004 were North African immigrants has not been lost on the EU. The growing emphasis on a securitised discourse has had notable effects for how the border is conceptualised, with the emphasis increasingly being on creating a border of control and exclusion. This, in turn, has been to the detriment of developmental and human rights aspects in EU policies towards the region. As Malmvig (2006) argues, EU policy towards the Mediterranean has been driven by two broad yet contradictory security discourses. The liberal reform discourse has emphasised democracy and human rights promotion perceiving that threats of terrorism, radicalisation, migration and organised crime derive 
from deeper political and social problems of the region, and most specifically are connected to the absence of democracy, the rule of law, basic freedoms and economic growth. Indeed, it is the authoritarian nature of the regimes in power and the cronyism, repression and violence that results from this that is seen as the crux of the problem. In contrast, the cooperative security discourse precisely sees these authoritarian regimes as partners in tackling the common challenges of terrorism, radicalism, WMD, organised crime, illegal immigration and so forth. Thus, whilst the first approach calls for concerted democratisation and liberalisation of rotten states and societies, the second approach calls for cooperation with those societies and regimes in tackling common threats. In Malmvig's judgement the EU has tended to favour security and regime stability over promoting democratisation and human rights, a trend that only seems to have strengthened since 9/11. The point, in other words, is that despite the progressive rhetoric in the EMP and ENP the prospects for transformation in the partner countries of the southern neighbourhood are viewed as slim. Indeed, the EU is ultimately prepared to tolerate unsavoury regimes in return for cooperation in the fight against terrorism. This smacks of a limes geostrategy where a final border is being drawn and ambitions to influence developments in the partner countries - perceived according to Malmvig (2006: 356) as 'equal Others' - are limited.

The third issue is one of identity. The key point here is that whereas the Europeanness of the eastern neighbourhood is broadly accepted, in the south this is much more contested and contributes to a rather static view of the nature of the EU's borders in the south. The issue, however, is not straightforward. For example, Holm identifies two broad identity 
discourses in the EU's approach to the southern neighbourhood. On the one hand, she notes there is the discourse of the Mediterranean as the cradle of civilisation, as a meeting place where cultures are able to fertilise each other. This discourse, she notes, leaves open possibilities of a future profitable co-existence and even of future closer integration. The other discourse, in contrast, is of the southern neighbours as riven by conflict and as cultural others. This discourse easily draws on the role of Islam versus a Christian Europe and in its rightist manifestations can entail racist elements in terms of the fear of the Arab other (Holm, 2005). In recent years it seems the second discourse has become stronger (not least spurred on by the war on terrorism) and can be seen in such things as attempts to get a reference to the Christian heritage of Europe included in the preamble to the draft Constitution, or in current debates about whether Turkey should be allowed to become an EU member with widespread comment arguing that the majority position of Islam in the country would pose a threat to Europe. As Valery Giscard d'Estaing declared in 2002:

If Turkey is going to be a member of the EU, it will result in the end of the EU because certain discussions cannot be expanded to countries that have another culture, another way of living (quoted in Holm, 2005: 8).

Giscard d'Estaing also warned that including Turkey would open the gates also to Morocco, whose earlier application in the 1980s was notably rejected on the simple grounds that Morocco is not a European country (Neumann, 1998). The result is that the current EU approach to the southern neighbourhood is driven by a strategy of 'containment in the face of a world that is viewed as profoundly alien' (Walters, 2004: 
692). In this context the southern border is viewed as somewhat fixed, though the fact that a more positive discourse exists of the Mediterranean as a meeting place and cradle of civilisation indicates that room for a shift to other geostrategies in the future also exists.

Finally, however, it should also be noted that the southern partners also play a constitutive role in how the geopolitics of Europe unfolds in the south. Key here is that whilst the eastern neighbours are clearly aspiring for membership, the southern neighbours, for the most part, are not and rather have a cautious approach to the EU as a whole. Thus, whilst potential benefits of closer relations are noted the regimes of the region also remain suspicious of the EU's rhetoric of democratisation and transformation, which is seen as a threat to regime security and as just the latest example of European colonialism. Since they are not proclaiming membership of the European club and are not aspiring for membership, this also undermines some of the key carrots behind the conditionality principle at the core of the ENP and makes the projection of EU influence and governance beyond the border difficult. In this sense, a limes geostrategy and vision of the EU as a consolidating empire is not only dictated by current preferences within the EU towards the south, but also by the preferences of the southern neighbours themselves.

\section{Northern Neighbourhood}

As indicated earlier in the article the situation in the northern neighbourhood has been somewhat different to that in the eastern and southern neighbourhoods. After the end of 
the Cold War regional cooperation in the North developed swiftly. Much of this cooperation was organic, emerging from below with the creation of ad hoc societysociety links across the former East-West divide. City and cultural networks flourished in the region and often largely beyond the control of the states. This was paralleled by topdown state sponsored initiatives such as the creation of the Council of the Baltic Sea States (CBSS) and the Barents Euro-Arctic Council (BEAC). As Neumann pointed out at the time, considerable idealism was present in the region with academics perceiving the North as an experimental space for overcoming previous divides, and as a space where constructivist and postmodernist theories envisaging transformation and emancipation could be put into practice (Neumann, 1994). In short, the emphasis was on discourses of opportunity and promoting a common sense of 'we-ness', and to the extent that security was on the agenda, it was seen as something held in common (Browning and Joenniemi, 2004).

Developments in the North were soon conceptualised in terms of discourses of neomedievalism, of breaking down the borders between the inside and outside of the EU, of creating overlapping spaces of jurisdiction and governance, and rather building the North on the basis of interlocking networks. In this respect, region-builders in the North frequently operated with a geostrategy of the networked (non)border to hand and of seeing developments in the North as presaging the creation of a postmodern neomedievalist geopolitics for Europe in general. Ultimately these visions came together in the Northern Dimension initiative (NDI) with its emphasis on multilateralism, partnership and equality between participants. 
However, alongside this neomedieval vision and a geostrategy of the networked (non)border others have pointed out that also present have been more traditional imperial frames and a geostrategy of the colonial frontier. This has been particularly evident in the NDI where a tendency to concentrate on exploiting Russian resources and organising Russian space has been evident and also where the idea of the EU as guiding Russia towards European civilisation has at times been clear (Browning, 2003). It has also been evident in that rather than always embracing the regionality inherent in the NDI, at times the EU has tended to see itself as at the apex of the decision-making hierarchy and tried to assert its dominant position over the CBBS, BEAC and other regional organisations and networks (Catellani, 2001).

In this broad context, however, the introduction of the ENP has been seen as challenging for the northern neighbourhood and a challenge for the NDI more particularly. The issue, in a sense, has been that whilst the ENP may work in the East its emphasis on bilateralism over regionality has been seen as at odds with the logic of regional cooperation in the North, where dealing with Russia in multilateral forums has been relatively unproblematic. Put more succinctly, whilst the East was a problem in need of a solution from the centre, the North does not seem to have needed any new, more centredirected policies, not least because Russia has not been perceived as an actor creating problems in a multilateral context (as has been the concern in the East). Indeed, the emphasis on homogenisation and standardisation in the ENP, its broadly defensive conceptualisation of the outside and tendency to draw a distinction between 'our' and 
'their' security, as well as its general emphasis on a limes geostrategy seemed to operate according to a largely different logic to the more open NDI with its tendency towards promoting decentralisation.

Similarly, Tassinari has pointed out that the logic of regional cooperation in the North has also differed significantly from that of the ENP in that unlike the latter it has not been tied so explicitly to the integration-security issue. In other words, the development of regional and cross-border cooperation in the North has not been developed in order to ward off further enlargement, since such questions have been treated as largely irrelevant (in the case of the Balts and Poland regionalisation has prepared them for membership whereas Russia has not been opting for membership). Instead it has been about creating spaces for interaction, dialogue and action in realms of common interests. As such, Tassinari (2005: 16-17) argues regionalism in the North has been far more inclusive than seems possible in the ENP. This is largely because it is not constrained by concerns of conditionality, othering and of reasserting hierarchies, but rather with developing common agendas among more genuinely equal partners.

Thus, although ENP documents have made positive reference to the lessons that might be garnered from the NDI experience (European Commission, 2004: 21), with its initiation there was a general feeling that the ENP might have signalled the demise of the NDI, or at the very least its subsuming under the more top down ENP. Even Russia's rejection of the ENP and its preference for dealing with the EU through the ‘strategic partnership’ did not change this feeling, not least because the general applicability of the ENP to all the 
EU's neighbours is reinforced by the fact that all neighbourhood policy funding will now be directed through its new financial instrument (ENPI), this implying that ENP principles (including that of conditionality) are now likely to apply also in the North. As such, whether Russia really has escaped the ENP's conditionality mechanism remains to be seen. Notably the Commission's europa website states that the development of the strategic partnership through the four common spaces must occur 'in consistency' with the ENP and its financial instrument, ${ }^{12}$ whilst the EU's apparent application of ENP 'benchmarks' to the Common Spaces is causing further frustration in Moscow (Averre, 2005: 180, 182-3).

In short, therefore, whereas the Union's impact in northern Europe in regard to the multilateral setting used to be relatively modest, the ENP appeared to mark a significant change. Despite its good record the North appeared likely to become increasingly conditioned by the challenges faced in the other neighbourhoods and the EU's general desire for more 'joint', 'coherent' and 'consolidated' policies in the post-enlargement situation. Put more specifically, it has seemed that fears of Russia's dominance in the eastern neighbourhood would also have a negative impact on northern cooperative constellations. The general direction has therefore been a move away from a neomedieval geopolitical model of the EU in the North, built around a geostrategy of the networked (non)border, towards a more imperial geopolitical model driven largely by a limes geostrategy.

\footnotetext{
12 ‘The European Neighbourhood Policy’, http://europa.eu.int/comm/world.enp/faq_en.htm. (Accessed July 2005).
} 
However, this does not appear to be carved in stone. The parties to the NDI have recently decided that the initiative 'requires some reshaping in order to better fit into the new operational environment'. A meeting of the foreign ministers, held in November 2005, stated this in accepting 'guidelines for the development of a political declaration and policy framework document for the Northern Dimension policy from 2007’. They spoke, in fact, about 'a new NDI' viewed as a regional expression of the four common spaces between the EU and Russia. In general, the emphasis was on open dialogue between parties with particular stress on Russia, Russia's equal position in the process and Russia's input into the talks on the 'new NDI'. ${ }^{13}$

The participation of the Russian foreign minister in the meeting and the drafting of the guidelines was, as such, seen as important since Russia had over a period been rather passive vis-à-vis the NDI, feeling that it had lost its momentum (Rettman, 2006). Premised on the guidelines, a political declaration on the Northern Dimension as 'a common regional policy' was endorsed at a summit meeting held in Helsinki in November 2006. With the establishment of a steering group to be in charge of the policy, the EU Commission's position was downgraded to one of the four partners, whereas that of Russia (together with Iceland and Norway) was upgraded to a more equal one. There was, hence, less emphasis on the NDI as part of the EU's external affairs and increased emphasis on its nature as a policy common to the partners in the region. Moreover, the

\footnotetext{
${ }^{13}$ Guidelines for the Development of a Political Declaration and a Policy Framework Document for the Northern Dimension Policy from 2007, http://ec.europa.eu/comm/external_relations/north_dim/doc/guidelines05.pdf.
} 
NDI was now set up as a 'permanent policy' rather than grounded on regularly revised Action Plans. ${ }^{14}$

One reason for such developments, of course, may be simply that in the context of the lack of democratic transition in Russia since the optimistic 1990s, and Russia's reassertion of itself as a great power under President Putin, rather pragmatic and strategic reasons have also emerged that encourage an emphasis on equality between partners in the North and that in turn may indicate the demise of the more idealism-driven narratives that promoted a similar dialogical approach in earlier years. The pragmatic emphasis stems from that (unlike the southern and eastern neighbours) Russia is a powerful actor, which makes it harder for the EU to assert itself and insist on the reproduction of EU norms and values in the Russian space. The strategic incentive for a dialogical approach is that Russia has assets (e.g., energy resources, support against terrorism) that the EU needs, with this in turn making the EU less prone than previously to prioritising its normative dimension.

\section{Conclusion}

In conclusion, therefore, by combining geopolitical models with geostrategies it is possible to get a more nuanced understanding of the dynamics of how the EU is approaching its border regions and new neighbourhood. Instead of depicting the EU as simply moving along a Westphalian, Imperial or Neomedieval trajectory, introducing

\footnotetext{
${ }^{14}$ Political Declaration on the Northern Dimension Policy, 24/11/06. http://ec.europa.eu/comm/external_relations/north_dim/doc/pol_dec_1106.pdf
} 
Walters' conception of geostrategies enables us to see that the EU can be Westphalian, Imperial and Neomedieval in different ways at different points along its border. Moreover, understanding geostrategies as discursive mental geographies by which the EU approaches its neighbourhood also enables us to impute complexity in that various geostrategies may be held at the same time, as well as to see dynamism as the dominance of one geostrategy may be replaced by another or a different combination of them with regard to the same neighbourhood. And as indicated, one reason for this dynamism is the simple fact that the member states and EU institutions may each have different interests and perspectives concerning the particular border region in question. Furthermore, into this mix we have also pointed to the constitutive role that the neighbours themselves can play in framing which geostrategies become viewed as attractive on the part of the EU. Thus, in regard to the eastern neighbourhood the emergence of a colonial frontier geostrategy has been as much a result of the continued European ambitions of the neighbours as it has reflected a preference on the part of the EU for further expansion. Indeed, the contrary is as much the case, where the ENP in the East was initially framed in terms of the more overtly exclusionary geostrategies of the limes and march.

The conceptual framework adopted also enables us to see another rather notable difference in how the EU conceptualises its self identity and global mission at different points along its border. Interesting is that as regards the eastern and southern neighbourhoods the EU has essentially adopted a rather uncompromising vision of itself in how the ENP is being articulated. This is a vision where EU norms, values, and practices are seen as non-negotiable. The difference between the eastern and southern 
neighbourhoods is the extent to which the projection and adoption of EU practices and values into the neighbourhood is seen as beneficial or otherwise by the outside. To the extent that the outside is generally amenable to the import of EU values and practices (as in the East) then EU threat perceptions are meliorated and the neighbourhood is easily envisaged as firmly embedded in the EU's new 'ring of friends'. In contrast, suspicion and rejection of EU practices has come to place states at a more distanced position and even as potentially threatening to the EU (as in the South). The difference between friendship and threat, between security and insecurity, therefore, in a rather subtle way, has, in the discourses surrounding the ENP, become a question of the extent to which outsiders are willing to become like us. This represents a very different understanding of threat to previous EU discourses, where the security concern was understood as avoiding a return to the EU's own past and where the order of the day was denying the previous European self. The message now is that the EU has become confident with its self such that security has now become conceptualised in terms of the ability of the EU to reproduce itself (its model and practices) in its external neighbourhood.

In the North, however, things seem to be different. The prevalence of geostrategies of the networked (non)border and the emphasis within the NDI on partnership and equality between members and non-members indicates a different logic and conception of self are operative. Rather than Russia's non-compliance and rejection of the ENP (and its universalising notion of what constitutes good practice) being conceived as problematic and as isolating Russia from the 'ring of friends' and even positioning Russia as a threat, a different approach is evident. Instead of the totalising liberal security view (that the 
outside must become like us or be considered potentially unfriendly and threatening) with regard to Russia a more traditional negotiated common security approach can be identified. The emphasis in the North rather seems to be on generating stability and understanding, without this being preconditioned on Russia's acceptance of key liberal values (as in the southern and eastern neighbourhoods). In the North the EU is exhibiting greater willingness to compromise. Consequently, the European neighbourhood looks different in the North as compared with the South and East. Not only are the processes of bordering different, but so too are the representations as to what the EU is about in that the identity constituted in the North is a less imperialistic one in that, unlike in the South and East where the goal is to remake the other in the image of the self, in the North more space is provided for dialogue and compromise with the other.

In this respect, it is also worth noting that with the 2007 enlargement the Union's borders have now extended to the Black Sea and where, interestingly, the approach favoured appears to be, in addition to ENP-inscribed bilateral relations, one of regionalisation. Thus, in its efforts of strengthening the ENP the Commission has recently stated that it is 'currently examining the possibility of establishing closer contacts' and a regular dialogue with the Black Sea Economic Cooperation Organisation (BSEC), and to which a separate communication will be devoted in 2007 (European Commission, 2006: 10-11).

Finally, highlighting this is not to take a normative stand on the issue of the practical implications of different combinations of geopolitical models and geostrategies. To reassert a point made at the beginning, whilst it may be tempting to draw 'logical' links 
between different geopolitical models and geostrategies, the analysis has highlighted that multiple combinations are possible. Similarly, it may also be tempting to try and formulate which combinations are more likely to produce stability and are more likely to be durable and to explain why. The reason we refrain from doing this is that in our view this will always depend on the relationship between the EU's aspirations and preferences (and those of salient member states) and the aspirations and preferences of the outsiders. The point is that emphasising particular models and geostrategies in one context may correlate well with the interests of particular neighbours and prove durable, whilst in another context they may appear highly provocative. This paper, therefore, is not a call for the generalisation of the dialogical networked (non)border approach of the Northern Dimension initiative premised on a geopolitical model of neomedievalism, but rather an attempt to highlight and conceptualise the dynamism and fluidity evident at the EU's borders. Indeed, if anything it is precisely this dynamism that should be championed as a valuable resource and as such avoiding the tendency to close off options through the reification of particular visions of the nature of the EU and its borders.

\section{Bibliography}

A Northern Dimension for the Policies of the European Union. A Video directed by P. Stenlund and M. Nissinen (1999). Virtual Finland. virtual.finland.fi/finfo/english/northdim2.html..

Albioni, Roberto (2005) 'The Geopolitical Implications of the European Neighbourhood Policy', European Foreign Affairs Review 10(1), pp.1-16.

Archer, Clive (2001) 'The Northern Dimension as a Soft-Soft Option for the Baltic States' Security', in Hanna Ojanen (ed.) The Northern Dimension: Fuel for the EU? (Helsinki \& Berlin: Finnish Institute of International Affairs \& Institute for European Politics) pp.188-208.

Averre, Derek (2005) 'Russia and the European Union: Convergence or Divergence?’, European Security 14(2), pp.175-202. 
Berg, Eiki and Ehin, Piret (2006) 'What Kind of Border Regime is in the Making? Towards a Differentiated and Uneven Border Strategy', Cooperation and Conflict, 41/1, pp.53-71

Browning, Christopher S. (2003) 'The Internal/External Security Paradox and the Reconstruction of Boundaries in the Baltic: The Case of Kaliningrad', Alternatives 28/5, pp.545-581.

Browning, Christopher S. (2003) 'The Region-Building Approach Revisited: The Continued Othering of Russia in Discourses of Region-Building in the European North', Geopolitics 8/1, pp.45-71.

Browning, Christopher S. (2005) 'Westphalian, Imperial, Neomedieval: The Geopolitics of Europe and the Role of the North', in Christopher S. Browning (ed.) Remaking Europe in the Margins: Northern Europe after the Enlargements (Aldershot: Ashgate) pp.85-101.

Browning, Christopher S. and Joenniemi, Pertti (2003) ‘The European Union's Two Dimensions: The Eastern and the Northern', Security Dialogue 34(4) pp.463-479.

Browning, Christopher S. and Joenniemi, Pertti (2004) 'Regionality Beyond Security? The Baltic Sea Region after Enlargement', Cooperation and Conflict 39(3) pp.233-253.

Catellani, Nicola (2001) ‘The Multilevel Implementation of the Northern Dimension', in Hanna Ojanen (ed.), The Northern Dimension: Fuel for the EU? (Helsinki: Ulkopoliittinen instituutti and Institut für Europäische Politik) pp. 54-77.

Christiansen, Thomas (1999) 'Between 'Ins' and 'Outs': EU Integration and Regional Policy-Making in North-Eastern Europe', in Lars Hedegaard and Bjarne Lindström (eds.), NEBI Yearbook: North European and Baltic Sea Integration (Berlin: Springer Verlag) pp.189-208.

Christiansen, Thomas (2005) 'Constitutionalising the European Union, Constructing EU Borders', in Christopher S. Browning (ed.) Remaking Europe in the Margins: Northern Europe after the Enlargements (Aldershot: Ashgate) pp.69-84.

Christiansen, Thomas and Joenniemi, Pertti (1999) 'Politics at the Edge: On the Restructuring of Borders in the North of Europe', in Heikki Eskelinen Ilkka Liikanen and Jukka Oksa (eds.), Curtains of Iron and Gold. Reconstructing Borders and Scales of Interaction (Aldershot: Ashgate) pp. 89-116.

Cimoszewicz, Wlodzimierz (2003) 'The Eastern Dimension of the European Union: The Polish View', speech at the conference 'The EU Enlargement and Neighbourhood Policy', Warsaw, 20 February 2003; available at http://www.msz.gov.pl (29 August 2003).

Council of the European Union (2000), Action Plan for the Northern Dimension with external and crossborder policies for the European Union 2000-2003, 14 June 2000, 9401/00.

Del Sarto, Rafaella A. and Schumacher, Tobias (2005) 'From EMP to ENP: What’s at Stake with the European Neighbourhood Policy towards the Southern Mediterranean?’ European Foreign Affairs Review 10(1), pp.17-38.

Emerson, Michael (2002) 'The Wider Europe as the European Union's Friendly Monroe Doctrine', CEPS Policy Brief, No.27/October 2002), http://www.ceps.be.

Emerson, Michael (2004) ‘European Neighbourhood Policy: Strategy or Placebo?’ CEPS Working Document, No.215/November 2004

Emerson, Michael and Noutcheva, Gergana (2005) ‘From Barcelona to Neighbourhood Policy. Assessments and Open Issues’. CEPS Working Document, No. 220/March 2005. 
European Commission (2003) Wider Europe Neighbourhood: A New Framework for Relations with our Eastern and southern Neighbours, COM (2003) 104 final, Brussels, 11.3.2003.

European Commission (2004) European Neighbourhood Policy - Strategy Paper, COM (2004) 373 final, Brussels 12.05.2004.

European Commission (2004) Proposal for a Regulation of the European Parliament and of the Council laying down general provisions establishing a European Neighbourhood and Partnership Instrument, COM (2004) 628 final, Brussels, 29.09.2004.

European Commission (2006) On Strengthening the European Neighbourhood Policy, COM(2006)726 final. Brussels, 04.12.2006.

Ferrero-Waldner, Benita, Commissioner for External Relations and European Neighbourhood Policy, 'Europe's Neighbours - Towards Closer Integration', speech delivered at the Brussels Economic Forum, Brussels, 22 April 2005.

Fererro-Waldner, Benita, 'The European Neighbourhood Policy: Helping Ourselves through Helping Our Neighbours', speech presented at the Conference of Foreign Affairs Committee Chairmen of EU Member and Candidate States, London 31 October 2005.

http://europa.eu.int/comm/external_relations/news/ferrero/2005/sp05_31-10-05.htm (Accessed 8 November 2005).

Filtenborg, Mette; Ganzle, Stefan and Johansson, Elisabeth (2002) 'An Alternative Theoretical Approach to EU Foreign Policy: 'Network Governance' and the Case of the Northern Dimension Initiative', Cooperation and Conflict 37(4) pp.387-407.

Grabbe, Heather (2000) 'The Sharp Edges of Europe: Extending Schengen Eastwards', International Affairs 76(3), pp.519-536.

Gromadzki, Gregorz; Lopata, Raimundas and Raik, Kristi (2005) Friends or Family? Finnish, Lithuanian and Polish Perspective on the EU's Policy Towards Ukraine, Belarus and Moldova (Helsinki: Finnish Institute of International Affairs, FIIA Report 12/2005).

Guidelines for the Development of a Political Declaration and a Policy Framework Document for the Northern Dimension Policy from 2007, http://ec.europa.eu/comm/external_relations/north_dim/doc/guidelines05.pdf.

Haukkala, Hiski (2001) Two Reluctant Regionalizers? The European Union and Russia in Europe's North, (UPI Working Papers 32), (Helsinki: The Finnish Institute of International Affairs).

Haukkala, Hiski (2005) ‘A Rocky Ride for the EU and its European Neighbourhood Policy’, OSCE Review 13(2) pp.10-11.

Holm, Ulla (2005) EU's Neighbourhood Policy: A Question of Space and Security (Copenhagen: DIIS Working Paper 2005/22). Available at http://www.diis.dk.

Jeandesboz, Julien (2005) 'The European neighbourhood policy: analysing the securitisation(s) of the Union's 'external border', paper presented at the COST Doctoral Training School, Critical Approaches to Security in Europe, Centre européen, Institut d'études politiques, Paris, 16-18 June 2005.

Joenniemi, Pertti (2000) ‘Changing Politics along Finland’s Borders: From Norden to the Northern Dimension', in Pirkkoliisa Ahponen and Pirjo Jukarainen (eds.), Tearing Down the Curtain, Opening the Gates: Northern Boundaries in Change (Jyväskylä, SoPhi) pp. 114-133. 
Joenniemi, Pertti and Sergounin, Alexander (2003) Russia and the European Union's Northern Dimension. Encounter or Clash of Civilisations? (Nizhny Novgorod State Linguistic University Press).

Knio, Karim (2005) A Tale of Two Economic Development Perspectives: Neoliberalism and its Alternatives in the ENP (Unpublished PhD manuscript, University of Birmingham).

Lehti, Marko (2005) 'Lost Moment of the North? National Reading of the Northern Dimension Initiative', presented at the Lund Nordic Geography conference, Sweden, 12-13 May 2005.

Lipponen, Paavo (1997) 'The European Union Needs a Policy for the Northern Dimension', speech presented at the ‘Barents Region Today’ conference, Rovaniemi, Finland. 15.09.1997.

Liulevicius, V. (2000) War Land on the Eastern Front: Culture, National Identity, and German Occupation in World War I (Cambridge, Cambridge University Press).

Malmvig, Helle (2006), 'Caught between cooperation and democratization: the Barcelona Process and the EU’s double-discursive approach’. Journal of International Relations and Development 9(4), pp.343-370.

Medvedev, Sergei (2000) Russia's Futures: Implications for the EU, the North and the Baltic Region (Helsinki, Ulkopoliittinen instituutti and Institut für Europäische Politik).

Medvedev, Sergei (2001) ‘The Blank Space: Glenn Gould, Russia, Finland and the North’, International Politics 38(1), pp.91-102.

Ministry of Foreign Affairs, Republic of Poland (2001) 'The Eastern Policy of the European Union in the Run-Up to the EU's Enlargement To Include the Countries of Central and Eastern Europe: Poland's Viewpoint' (Warsaw; Ministry of Foreign Affairs).

Moroff, Holger (ed.) (2002) European Soft Security Policies: The Northern Dimension (Helsinki and Berlin: Finnish Institute or International Affairs and Institut für Europäische Politik).

Neumann, Iver B. (1994) 'A Region-Building Approach to Northern Europe', Review of International Studies 20(1), pp.53-74.

Neumann, Iver B. (1998) ‘European Identity, EU Expansion and the Integration/Exclusion Nexus', Alternatives 23(3), pp. 397-416.

Pace, Michelle (forthcoming) 'People-to-People: Education and Culture', in Katja Weber, Michael E. Smith and Michael Baun (eds.), Governing Europe’s New Neighbourhood: Partners or Periphery? (Manchester University Press).

Pardo, Sharon (2004) ‘Europe of Many Circles: European Neighbourhood Policy’, Geopolitics 9(3) pp.73137.

Pardo, Sharon and Zemer, Lior (2005) 'Towards a New Euro-Mediterranean Neighbourhood Space', European Foreign Affairs Review 10(1), pp.39-77.

Parker, Noel (2000) 'Integrated Europe and its “Margins”: Action and Reaction', in Noel Parker and Bill Armstrong (eds.), Margins in European Integration (Houndmills, Macmillan Press) pp. 3-27.

Political Declaration on the Northern Dimension Policy, 24/11/06.

http://ec.europa.eu/comm/external_relations/north_dim/doc/pol_dec_1106.pdf

Rettman, Andrew (2006) 'EU and Russia to cement their relations in new northern treaty', EUObserver 01.09.2006. 
Ruggie, John Gerard (1993) 'Territoriality and Beyond: Problematising Modernity in International Relations’, International Organization, Vol. 47(1), pp.139-74.

Saarikoski, Vesa (1997) 'Introduction: The Europe Between', in Vesa Saarikoski (ed.) And Never Shall They Meet? European Space and Thought Between East and West (Turku: Department of Political History, University of Turku, Publications 6) pp.7-16.

Scott, James (2005) 'The EU and 'Wider Europe': Towards an Alternative Geopolitics of Regional Cooperation?’, Geopolitics, 10/3, pp.429-54.

Sergounin, Alexander (2005), 'The Russian Debate on “Old”/”New” Europe.' Paper presented at the ISA Congress, 28 February-5 March, Honolulu.

Smith, Karen E. (2005) 'The Outsiders: The European Neighbourhood Policy’, International Affairs 81(4), pp.757-773.

Stålvant, Carl-Einar (2005) 'Transnational Forces, States and International Institutions: Three Perspectives on Change in Baltic Sea Affairs', in Christopher S. Browning (ed.) Remaking Europe in the Margins: Northern Europe after the Enlargements (Aldershot: Ashgate) pp.181-202.

Tassinari, Fabrizio (2005) 'Security and Integration in the EU Neighbourhood: The Case for Regionalism', CEPS Working Document, No.226/July 2005.

Tiirmaa-Klaar, Heli, 'EU's Governance Methods in its Neighbourhood Policy', presented at the CEEISA annual conference, Tartu, 25-27 June 2006

Vahl, Marius (2005) 'Lessons from the North for the EU's 'Near Abroad', in Christopher S. Browning (ed.) Remaking Europe in the Margins: Northern Europe after the Enlargements (Aldershot: Ashgate) pp. 51-67.

Walters, William (2004) 'The Frontiers of the European Union: A Geostrategic Perspective', Geopolitics, 9/3, pp.674-98.

Wæver, Ole (1997) 'Imperial Metaphors: Emerging European Analogies to Pre-Nation-State Imperial Systems’, in Ola Tunander, Pavel Baev and Victoria Ingrid Einagel (eds.), Geopolitics in Post-Wall Europe: Security, Territory and Identity (London: Sage) pp. 59-93.

Zaslavskaya, Natalia (2005) Paper on the EU Neighbourhood Policy presented at The Fourth Northern Dimension's Network Meeting, St. Petersburg State University, Russia, 19-20 September 2005.

Zielonka, Jan (2001) 'How New Enlarged Borders will Reshape the European Union', Journal of Common Market Studies, Vol. 39(3), pp.507-36. 